\title{
Sacroiliac Joint Involvement in von Recklinghausen Neurofibromatosis
}

\author{
Olfa SAIDANE, Ines CHERIF, Rawdha TEKAYA, Ines MAHMOUD, Leila ABDELMOULA
}

Department of Rheumatology, Charles Nicolle Hospital, Tunis, Tunisia

\begin{abstract}
Neurofibromatosis (NF) type I is a genetic disorder caused by a mutation of the NF type I gene. This disease is associated with a variety of skeletal manifestations. In this article, we report a 33-year-old female patient with a known history of von Recklinghausen's disease and inflammatory right buttock pain. Diagnostic imaging pointed out unilateral sacroiliitis possibly of a septic origin. Sacroiliac biopsy showed histological patterns consistent with NF. This case report summarizes an exceptional localization of NF mimicking the imaging of infectious sacroiliitis.

Keywords: Neurofibroma; neurofibromatosis type l; sacroiliac joint.
\end{abstract}

Neurofibromatosis type I (NF-1), also named von Recklinghausen's disease, is a genetic disorder caused by a mutation of the NF-1 gene. ${ }^{1}$ This genetic disorder alteration can either be inherited through an autosomal dominant lineage, or may result through de novo spontaneous mutations of NF-1. Clinically, NF-1 is characterized by café-au-lait spots, freckling, skin neurofibroma, plexiform neurofibroma, bony defects, Lisch nodules, and tumors of the central nervous system. $^{2}$

Neurofibromas have been reported to cause accelerated bone and soft tissue growth. ${ }^{3}$ This can result in a variety of skeletal manifestations with spinal abnormalities being far and away the most common manifestation. ${ }^{4}$

Intra-articular involvement of NF-1 is rare. In this article, we report an exceptional case of NF localized in the sacroiliac joint which was examined in terms of clinical, radiological, histopathological, and therapeutic aspects.

\section{CASE REPORT}

A 33-year-old female patient admitted to the Department of Rheumatology with inflammatory right buttock pain for the past 18 months. She had a known history of von Recklinghausen's disease with multiple café-au-lait spots. Buttock pain was not associated with fever or impaired general conditions or other axial/peripheral articular manifestations. Physical examination revealed numerous and diffuse characteristic skin lesions including café-au-lait spots and neurofibromas. We noted pain in midline sacral thrust and while mobilizing the right sacroiliac joint. Erythrocyte sedimentation rate was $28 \mathrm{~mm} /$ hour and $\mathrm{C}$ reactive protein was $5 \mathrm{mg} / \mathrm{dL}$. Serum protein electrophoresis, calcium, and phosphorus levels were normal. Wright and Widal tests were negative. Sputum and urine tests for TB were also negative. However, tuberculin skin test was at $13 \mathrm{~mm}$. A written informed consent was obtained from the patient. 


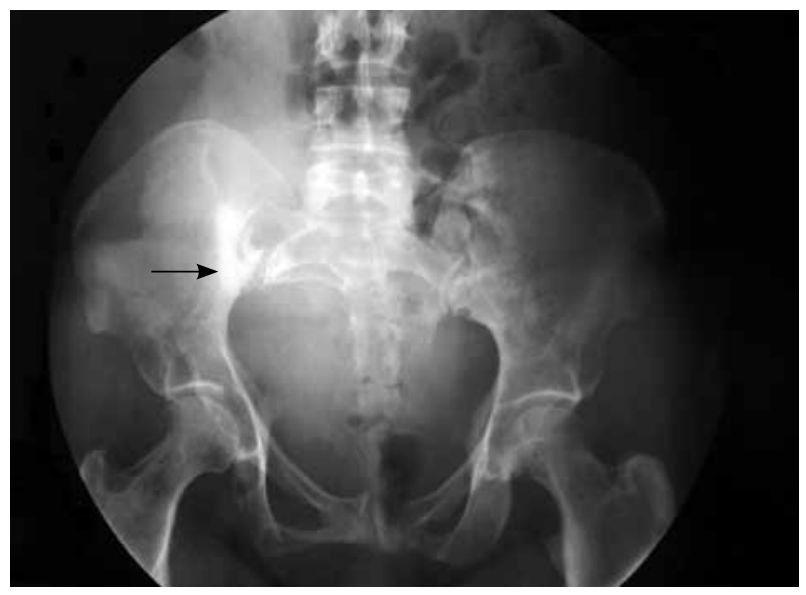

Figure 1. Radiography of pelvis showing a condensation of right sacroiliac joint (arrow) reflecting unilateral sacroiliitis.

The radiographic exam of the pelvis pointed out a condensation of the right sacroiliac joint reflecting unilateral sacroiliitis (Figure 1). Osseous defects of the sacrum, iliac bones, and right femur were also noted. Pelvis computed tomography scan showed a sacroiliac joint space narrowing associated with sclerosis and microgeodes which might suggest a septic sacroiliitis, particularly of tuberculous or Brucella origin. Multiple bone defects of the sacrum and iliac bones and enlargement of sacral foramina corresponding to multiple neurofibromas (Figure 2) were also noted. Magnetic resonance imaging revealed a juxtaarticular plexiform neurofibroma with massive invasion of the right sacroiliac joint and soft tissue (Figure 3). Tuberculous origin and malignant transformation were both discussed. Sacroiliac biopsy was performed showing histological patterns consistent with NF, with fusiform cells and fibrillary cytoplasm making a typical lemuroid appearance. Patient was referred to surgery.

\section{DISCUSSION}

To the best of our knowledge, this is the first case of a patient with sacroiliac involvement of NF-1 manifesting as an inflammatory unilateral buttock pain mimicking an infectious sacroiliitis.

Neurofibromatosis is a hamartomatous disorder of cellular components of neural crest origin. The neural crest is a transitory embryonic structure whose cells form neuronal, neuralsupportive, pigmentary, endocrine, and other tissues. In classical NF-1, skeletal defects occur as a result of abnormalities of the neuroectoderm and mesoderm. ${ }^{5}$

Skeletal involvement is one of the manifestations of the disease. In fact, neurofibromas have been reported to cause accelerated bone and soft tissue growth. ${ }^{3}$ Sometimes, the involvement is extremely severe, appearing from birth or becoming evident early in the childhood or adolescence
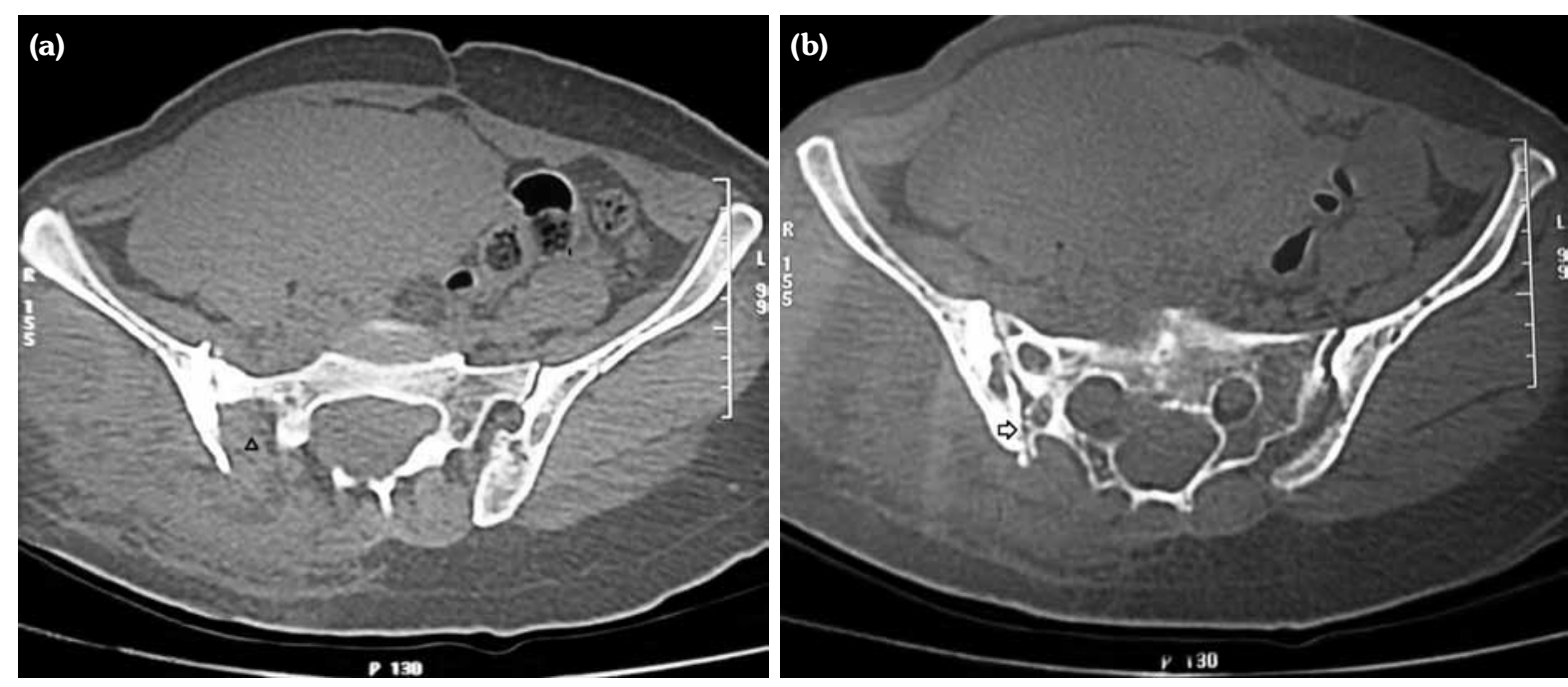

Figure 2. (a) Pelvis computed tomography scan showed multiple bone defect of sacrum and iliac bones and enlargement of sacral foramina (arrowhead) corresponding to multiple neurofibromas. (b) Pelvis computed tomography scan showed a sacroiliac joint space narrowing associated with sclerosis and microgeodes (arrow). 

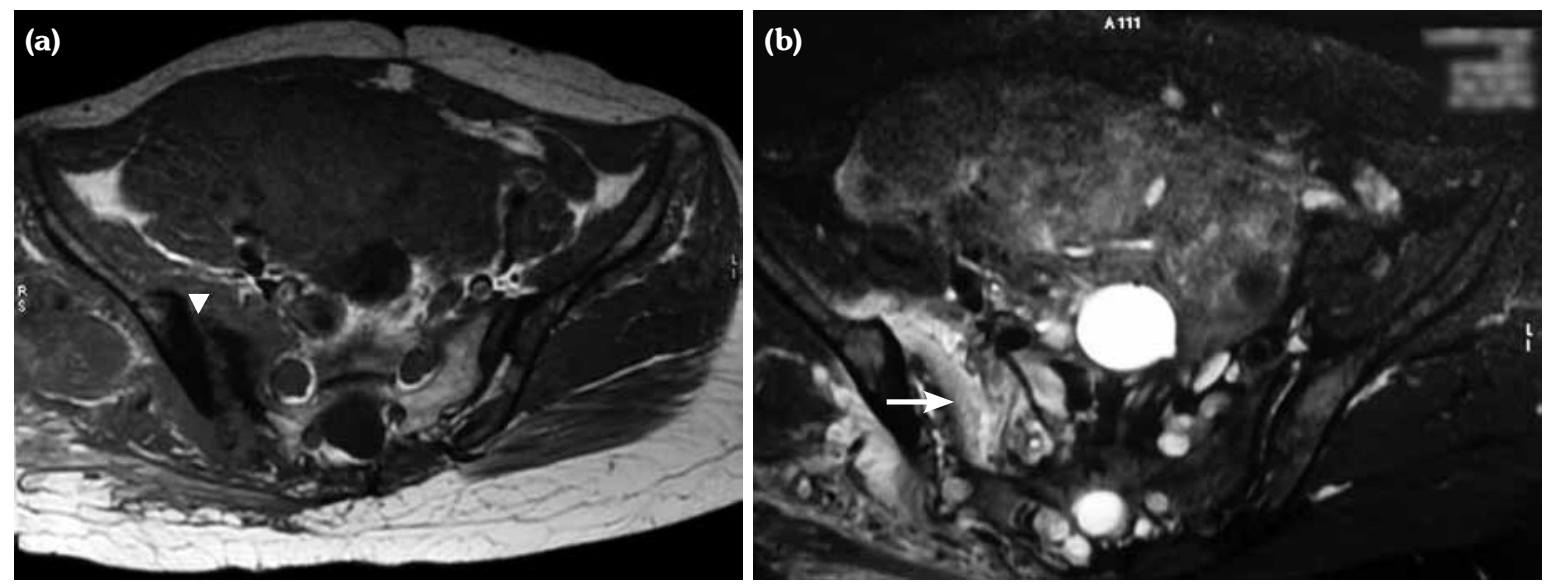

Figure 3. Magnetic resonance imaging. (a) $\mathrm{T}_{1}$-weighted image: juxtaarticular plexiform neurofibroma (arrowhead) with massive invasion of the right sacroiliac joint and soft tissue. (b) $\mathrm{T}_{2}$-weighted short-tau inversion recovery image: juxtaarticular plexiform neurofibroma with massive invasion of right sacroiliac joint and soft tissue (arrow).

and accentuating with the age. ${ }^{6}$ Spine, long bones, and craniofacial bones are the main localizations of NF-1. Involvement of the spine includes scoliosis. ${ }^{6}$ Involvement of long bones is represented by pseudoarthrosis particularly of the tibia, although similar lesions may occur in radius or clavicle. ${ }^{7}$

Radiologic findings may include deformities, soft tissue swelling, pseudoarthrosis, scalloping aspect of vertebral bodies, and rib tabulation. ${ }^{5}$ Magnetic resonance imaging is a useful tool of evaluating the extent of NF. Nevertheless, imaging features may be misdiagnosed as infectious or tumoral lesions. ${ }^{8}$

Intra-articular neurofibromas appear quite rare, limited to a few case reports., ${ }^{7,-15}$ The rare cases of hip or knee joint involvement have occurred in patients with NF-1 by a process of intra-articular penetration of neurofibromas originating in extraarticular locations. These extra-articular tumors can cause bony erosion and deformity, and even joint dislocation by intraarticular extension. ${ }^{7,14,15}$

In our case, involvement of sacroiliac joint was secondary to juxtaarticular plexiform neurofibroma with massive invasion of the right sacroiliac joint. Infectious investigations were normal and there was no argument of spondyloarthritis. Imaging features including magnetic resonance imaging were useful to identify plexiform neurofibroma, whereas they were insufficient to eliminate malign transformation. Thus, histological examination established the diagnosis.

\section{Declaration of conflicting interests}

The authors declared no conflicts of interest with respect to the authorship and/or publication of this article.

\section{Funding}

The authors received no financial support for the research and/or authorship of this article.

\section{REFERENCES}

1. Holtzman L. Radiographic manifestation and treatment considerations in a case of multiple neurofibromatosis. J Endod 1998;24:442-3.

2. Tanito K, Ota A, Kamide R, Nakagawa H, Niimura M. Clinical features of 58 Japanese patients with mosaic neurofibromatosis 1. J Dermatol 2014;41:724-8.

3. Gutmann DH, Aylsworth A, Carey JC, Korf B, Marks $\mathrm{J}$, Pyeritz RE, et al. The diagnostic evaluation and multidisciplinary management of neurofibromatosis 1 and neurofibromatosis 2. JAMA 1997;278:51-7.

4. Patel J, Whiting J, Jones D. Secondary Knee Osteoarthritis due to Neurofibromatosis Type 1 Treated with above the Knee Amputation: A Case Report. Case Rep Orthop 2013;2013:782106.

5. Hekmatnia A, Ghazavi A, Marashi Shooshtari MJ, Hekmatnia F, Basiratnia R. Imaging review of neurofibromatosis: helpful aspects for early detection. Iran J Radiol 2011;8:63-74.

6. De Gauzy S, Lemaire O, Acadbled F, Zabraniecki L. Manifestations orthopédiques des phacomatoses. 
EMC-Appareillocomoteur 2008:1-10

7. Kelly DW, Ovanessoff SA, Rubin JP. Intra-articular neurofibroma: an unusual source of anterior knee pain. Am J Orthop (Belle Mead NJ) 2012;41:492-5.

8. Zahir ST, Sharahjin NS, Dadgarnia MH. Primary parapharyngeal and skull base synovial sarcoma in a 13-year-old boy with neurofibromatosis radiologically misdiagnosed as a benign lesion. BMJ Case Rep Published online 2013, 3 June.

9. Aguiar R, Wong J, Pathria M, Baird S, Resnick D. Intraarticular neurofibroma of the hip. $\mathrm{J}$ Comput Assist Tomogr 2006;30:865-7.

10. Lokiec F, Arbel R, Isakov J, Wientroub S. Neuropathic arthropathy of the knee associated with an intraarticular neurofibroma in a child. J Bone Joint Surg [Br] 1998;80:468-70.

11. Van Damme PA, Freihofer HP, De Wilde PC. Neurofibroma in the articular disc of the temporomandibular joint: a case report. J Craniomaxillofac Surg 1996;24:310-3.

12. Mandell GA, Harcke HT, Scott CI, Caro PA, Einsig HJ, Bowen JR. Protrusio acetabuli in neurofibromatosis: nondysplastic and dysplastic forms. Neurosurgery 1992;30:552-6.

13. Joseph KN, Bowen JR, MacEwen GD. Unusual orthopedic manifestations of neurofibromatosis. Clin Orthop Relat Res 1992;278:17-28.

14. Lachiewicz PF, Salvati EA, Hely D, Ghelman B. Pathological dislocation of the hip in neurofibromatosis. A case report. J Bone Joint Surg [Am] 1983;65:414-5.

15. Haga N, Nakamura S, Taniguchi K, Iwaya T. Pathologic dislocation of the hip in von Recklinghausen's disease: a report of two cases. J Pediatr Orthop 1994;14:674-6. 